\title{
The Effect of Religiosity on Tax Fraud Acceptability: A Cross-National Analysis
}

\author{
STEVEN STACK \\ AUGUSTINE KPOSOWA
}

\begin{abstract}
Religion provides an important basis for social integration and the prevention of deviant behavior, such as tax fraud, a crime that costs society billions of dollars in lost revenue. The literature on tax fraud and tax fraud acceptability (TFA) has neglected religiosity as a social bond that may deter this type of behavior. Furthermore, existing work is based on the United States; there are no systematic cross-national studies. In particular, there is no research exploring the "moral communities" hypothesis that religiosity's effect on deviance will vary according to the strength of national moral communities. The present study addresses these two gaps in the literature by analyzing data on 45,728 individuals in 36 nations from the World Values Surveys. We control for other predictors of TFA, including social bonds, economic strain, and demographic factors. The results determined that the higher the individual's level of religiosity, the lower the TFA. Results on the moral community's hypothesis were mixed. However, in a separate analysis of individual nations, the presence of a "moral community" (majority of the population identifies with a religious group) explained 39 percent of the variation in the presence or absence of the expected religiosity-TFA relationship. Furthermore, the presence of a communist regime in a nation, often known for the oppression of religious groups who then may view the regime as illegitimate, diminished the impact of religion on TFA.
\end{abstract}

One consequence of high levels of religiosity in society can be low rates of deviant behavior, including tax fraud. The significance of tax fraud can be assessed in its economic impact on government. It has become increasingly clear that the capacity of governments to raise revenue is substantially affected by tax evasion (e.g., Hessing et al. 1992:405-06). For example, 7.5 percent of Britain's gross national product escapes taxation while 17 percent of the taxable income in Belgium remains undeclared. In the United States, the amount of tax revenue lost to tax cheating is approximately 20 percent (Grasmick, Bursik, and Cochran 1991:255). A review of 18 studies found that, on average, 20 percent of the population of taxpayers acknowledges cheating on their income taxes. This may be an underestimate because IRS data sometimes report that 35 percent of the returns that they audit are marked by cheating (Hessing, Effers, and Weigel 1988). Hence, tax fraud is a crime with substantial economic consequences involving billions of dollars in lost revenue. This amount dwarfs the profits made in all robberies, larcenies, burglaries, and a host of other street crimes against property (e.g., Brown, Esbensen, and Geis 2001). In short, if the proportion of persons who cheat on their income taxes increases, tax revenues will fall, with economic consequences. Religion, however, has never been applied to the problem of explaining cross-national variation in cultural attitudes toward tax fraud. This article focuses on the importance of religion in shaping cultural attitudes on the unacceptability of tax fraud.

The general literature on the effects of religion on deviant attitudes/behavior is consistent. The vast majority of papers have found an inverse association - the greater the individual-level religiosity, the lower the risk of deviant behavior (see Agnew 1998; Baier and Wright 2001; Tittle and Welch 1983). A recent meta-analysis of 60 studies determined that the mean reported effect size was $r=-0.12$, indicating the greater the religiosity the less likely people are to

Steven Stack is a Full Professor of Criminal Justice at Wayne State University, 2305 Faculty Administration Building, Detroit, MI 48202; Stack was a Visiting Scholar, Department of Sociology at the University of Michigan, Ann Arbor while working on this project.E-mail: aa1051@wayne.edu,steven_stack@hotmail.com Augustine Kposowa is a Full Professor of Sociology at the Department of Sociology, University of California, Riverside, CA 92507.E-mail:ajKposowa@worldnet.att.net 
engage in various crimes (Baier and Wright 2001). While this average association is not strong, it is consistent across a number of measures of delinquency, and an assortment of measures of religion.

The present study keys in on five weaknesses of the literature on religion and deviant attitudes/behavior. First, the overwhelming majority of studies fail to test the moral communities hypothesis that holds that individual-level religiosity will have the strongest effect on deviance when individual-level religiosity is reinforced by a high level of religiosity in the community (Baier and Wright 2001; Regnerus 2003; Stark 1996). Second, there is a dearth of cross-national investigations. It is unclear if the moral communities hypothesis might hold at the national level of analysis. It is also unclear if non-Western religions have the same "protective" effect on deviance as Western religions. Third, almost all of the relevant studies are limited to juveniles (e.g., Baier and Wright 2001; Regnerus 2003). Religiosity may have more of an impact on the deviance of adults, whose reported religiosity levels are apt to be more accurate. Adults, for example, are less likely to be forced by parents to attend religious services, making church attendance a more accurate measure of true religiosity. Fourth, major categories of deviance have been neglected, including violent crime and white-collar crime. For example, few studies on homicide rates incorporate a measure of religiosity into their models (Land, McCall, and Cohen 1990), and white-collar crimes have been neglected (e.g., Baier and White 2001; Brown, Esbensen, and Geis 2001). The existing research on religion and criminality focuses on street offenses including larceny, burglary, underage drinking, and drug use, rather than white-collar and occupational crimes such as price fixing, securities fraud, embezzlement, and tax fraud. Fifth, researchers have focused on the influence of religiosity on behavior to the neglect of religion's effect on attitudes toward deviant behavior. To the extent that behavior and attitudes are mutually reinforcing in general (e.g., Bem 1970; Festinger 1964), and for deviant behavior in particular (e.g., Warr and Stafford 1991), a full picture of the role of religion in controlling crime and deviance needs to assess religion's affect on both attitudes and behavior. For example, religion tends to be the single best predictor of attitudes toward suicide (e.g., Agnew 1998; Stack, Wasserman, and Kposowa 1994). The relative importance of religion in controlling public opinion on the legitimacy of criminal deviant behavior remains somewhat ambiguous.

The present study contributes to the literature by addressing some of the neglected issues in the previous research. First, it tests the moral communities hypothesis through the employment of appropriate strategies including multi-leveling modeling techniques. This allows for assessing the extent to which religion shapes individual behavior at the individual and group levels. Second, it employs data from 36 nations. This enables us to test the moral communities hypothesis using the nation as the unit of analysis, and to explore the effect of Eastern religions on deviance. Third, it extends the analysis to attitudes toward deviance among adults, a neglected group in the research on religion and deviance. Fourth, the present investigation concerns attitudes toward a white-collar crime, tax fraud. Fifth, the analysis focuses on attitudes as its dependent variable, a neglected component of the deviant behavior equation.

\section{Attitudes and Behavior}

Some caution needs to be exercised in interpreting our results here. The present study focuses on attitudes, or tax fraud acceptability, not actual tax fraud. Nevertheless, attitudes and behavior often tend to be strongly linked (e.g., Bem 1970). This tends to be the case in the analysis of criminological variables in general (e.g., Akers 2003; Warr and Stafford 1992), and tax fraud in particular (e.g., Dean, Keenan, and Kenney 1980; Hessing, Effers, and Weigel 1988; Hessing et al. 1992; Patee, Milner, and Welch 1994:95; Sheffrin and Triest 1992; Spicer and Lundstedt 1976; Thurman, St. John, and Riggs 1984; Varma and Doob 1998). Because tax fraud acceptability (TFA) has been linked to reported tax fraud in essentially all of the past relevant investigations 
on the subject, we anticipated that factors related to tax fraud acceptability would be predictive of reported tax fraud behavior. However, the data set we use here contains information only on attitudes.

The present investigation will contribute the first rigorous results on a series of issues: the relative importance of religion as a Level 2 variable in comparative perspective; the relative importance of Eastern religions in shaping tax fraud attitudes; and the relationship between tax fraud attitudes and measures of individual-level religiosity in a large sample of nations.

\section{Theoretical Framework}

The present article incorporates and tests two levels of explanations for the influence of religion on deviant behavior. The first is the dominant perspective, which assesses the influence of the religious characteristics of individuals on individual-level deviant behavior and attitudes. The second assesses the influence of the religious characteristics of groups on the deviance of individuals (and deviance of groups) (Regnerus 2003; Stark 1996).

\section{Level 1 Explanations of Religion and Deviance}

Religiosity is thought to contribute to lower risk for deviant behavior and attitudes in several ways. First, religions socialize people in such a way to discourage deviant beliefs and behavior (e.g., thou shalt not steal, thou shalt not kill). They provide negative definitions of deviance. Furthermore, they often deter deviance and promote anti-deviant attitudes through threats of eternal damnation, time spent in purgatory, and so forth (e.g., Baier and Wright 2001; Tittle and Welch 1983). In the case of tax fraud, the Christian scriptures explicitly condemn tax evasion (Grasmick, Bursik, and Cochran 1991:255). These negative definitions, in turn, should reduce criminality (e.g., Akers 2003). The emphasis on religious beliefs antithetical to deviance can be related to social control theory (e.g., Hirschi 1969). While religious bonds were not discussed in the original social control model, religious bonds including belief systems would be expected to deter adult criminality (Baier and Wright 2001:4; Regnerus 2003).

A second way in which religion can reduce criminality is through peer associations. Differential association reduces criminality through social selection and peer socialization. Religion affects selection in that religious individuals tend to select individuals with similar anti-deviant beliefs as close associates. Through socialization, association with like-minded religionists tends to result in positive reinforcement of conventional behavior (e.g., Baier and Wright 2001; Burkett and Warren 1987).

Religion can reduce the incidence of deviance through providing various coping mechanisms (e.g., prayer, meditation, belief in a blissful afterlife) that may reduce deviant responses to stressful life events and other pressures in life. Religious people generally have significantly better mental and physical health than less religious or nonreligious persons (see Hackney and Sanders 2003; Koenig and Larson 2001; Koenig, McCullough, and Larson 2001). Those with relatively high levels of religiosity have lower levels of emotional states such as anxiety and depression that researchers often view as moderating the relationship between stressful life events and deviant behavior and attitudes (e.g., Agnew 1992; Stack 1983).

Furthermore, we would also anticipate a reduction in deviance among religious people from the standpoint of rational choice theory. Religiosity contributes to the formation of perceptions of the certainty and severity of punishments from deviance (Casey and Scholz 1991; Grasmick, Bursik, and Cochran 1991). Highly religious persons are likely to experience psychological shame from deviant acts and those involved in religious networks are more likely than others to experience embarrassment when involved in deviance. These two negative psychological consequences, shame and embarrassment, are linked to lower criminality through their associations 
with perceived certainty and severity of punishment (Baier and Wright 2001; Grasmick, Bursick, and Cochran 1991).

\section{Level 2 Explanations: The Moral Community Hypothesis}

Of the limitations in the previous research perhaps one of the most significant is the relative inattention given to the moral community hypothesis. This hypothesis was first formulated by Durkheim (1961), but popularized mainly by Stark (1996). Herein the full effect of religiosity on crime will be felt only in areas that are marked by a relatively high level of aggregate religiosity. Areas with high levels of religiosity can most adequately reinforce the religious tendencies in individuals through sustained interaction. In contrast, in cities or nations where there are few religious individuals, religious individuals may not get their own religious norms adequately reinforced by contact with disproportionately fewer religious or like-minded persons in everyday life. This perspective is seldom tested (Baier and Wright 2001; Durkheim 1961; Regnerus 2003; Stark 1996; Welch, Tittle, and Patee 1991).

There are several other extensions of the basic moral communities hypothesis (Stark 1996; Regnerus 2003). Communities with a strong moral community may be expected to reduce the deviant attitudes and behavior of individuals in them regardless of the individuals' own level of religiosity (Regnerus 2003:524). Persons with relatively low levels of personal religiosity may be influenced by the attitudes and behavior of the persons with high levels of religiosity in the greater community. Hence, moral communities may strengthen religious attitudes and beliefs for everyone in them, even those who are irreligious. Some of the strongest evidence that moral communities reduce the deviant behavior of religious and less religious people in a community comes from sociological analyses of suicide rates. For example, county-level suicide rates (which count the suicides of both adherents and nonadherents) are lower in counties with strong moral communities (Pescosolido 1990; Regnerus 2003:526).

A further refinement of the moral communities hypothesis argues that the degree of religious homogeneity of a moral community may further strengthen its hold over the attitudes and behavior of individuals. For example, communities that are 90 percent Lutheran and 10 percent Catholic may be able to control individuals more effectively than communities that are 50 percent Lutheran and 50 percent Catholic (Regnerus 2003:526). As another example, research on metropolitan suicide rates determined that the extent to which religion deters suicide is related to the extent to which residents of a community adhere to a single religion (Ellison, Burr, and McCall 1997).

Finally, recent work suggests that the influence of religious homogeneity itself may be maximized in the context of relatively conservative religious faiths. For example, metropolitan suicide rates were most strongly related to the proportions of persons from two particular religious faiths: Catholicism and conservative Protestantism (Ellison, Burr, and McCall 1997). Furthermore, using data from the National Longitudinal Study of Adolescent Health, Regnerus (2003) determined that indicators of delinquency were often strongly associated with the proportion of conservative Protestantism in metropolitan areas and schools (as Level 2 contextual variables).

\section{Previous Research on Tax Fraud and Religion}

There is essentially no published research on the influence of religiosity on tax fraud acceptability. This includes both Level 1 and Level 2 models of religious effects. Given the dearth we draw on a related literature - studies of religion's impact on actual tax fraud behavior. We will divide this literature into two parts. The first (most studies) deals with Level 1 explanations: individual-level religiosity affecting individual behavior. The second set of studies deals with aggregate religious effects on individual tax fraud behavior. 


\section{Studies on Religion and Tax Fraud}

Most research on tax fraud does not include an indicator of religiosity (e.g., Clotfelter 1983; Grasmick and Bursik 1990; Hessing et al. 1992; Klepper and Nagin 1989a, 1989b; Spicer and Lundstedt 1976; Scott and Grasmick 1981; Smith 1990; Thurman 1989; Varma and Doob 1998; Vogel 1974). A search through online databases (sociological abstracts, criminal justice abstracts) and other sources uncovered only five studies on tax fraud that included a measure of religiosity (Grasmick, Bursik, and Cochran 1991; Grasmick, Kinsey, and Cochran 1991; Patee, Milner, and Welch 1994; Tittle and Welch 1983; Welch, Tittle, and Patee 1991). A sixth study by Tittle (1977) includes church attendance in a much larger index of differential association, which, in turn, is related to the incidence of tax fraud. Because the relative contribution of religion to the strength of the association between the overall index and tax fraud is not known, we omit this study. The results of the five relevant studies are summarized in Table 1. Grasmick, Bursik, and Cochran (1991) explored the influence of religious salience and church attendance on tax fraud in Oklahoma City. Both variables were significantly and negatively related to tax fraud at both the bivariate and multivariate levels of analysis. Grasmick, Kinsey, and Cochran's (1991) second report on their Oklahoma City study included a slightly different mix of variables. Religiosity was again indexed in terms of church attendance, but affiliation measures (fundamentalist and no affiliation) were substituted for the former index of religious importance. The set of control variables was almost the same set as in the earlier study, but political conservatism was dropped. Both fundamentalist affiliation and church attendance were negatively related to tax cheating, as anticipated.

Grasmick's investigations are both based on a single city, Oklahoma City. However, Oklahoma City may not be representative of the United States, as religion is typically stronger in that section of the nation. Hence, an unmeasured "moral community" effect may be enhancing the relationship

TABLE 1

\section{SUMMARY OF STUDIES ON TAX FRAUD THAT INCLUDE RELIGIOSITY AS AN INDEPENDENT VARIABLE}

\begin{tabular}{|c|c|c|c|c|c|c|c|}
\hline $\begin{array}{l}\text { First } \\
\text { Author }\end{array}$ & Year & $N$ & Place & $\begin{array}{c}\text { Bivariate } \\
\text { Finding }\end{array}$ & $\begin{array}{l}\text { Multivariate } \\
\text { Finding }\end{array}$ & Controls & Measure \\
\hline Grasmick & $1991 \mathrm{a}$ & 304 & Oklahoma City & $\begin{array}{l}r=-0.32^{*} \\
r=-0.26^{*}\end{array}$ & $\begin{array}{l}B=-0.213^{*} \\
B=-0.138^{*}\end{array}$ & $\begin{array}{l}\text { A,G,P,R,SES } \\
\text { A,G,P,R,SES }\end{array}$ & $\begin{array}{l}\text { RS } \\
\text { ATT }\end{array}$ \\
\hline Grasmick & $1991 b$ & 285 & Oklahoma City & $\begin{array}{l}\text { NA } \\
\text { NA } \\
\text { NA }\end{array}$ & $\begin{array}{l}p=0.022^{*} \\
P=0.132 \\
P=0.005^{*}\end{array}$ & $\begin{array}{l}\text { A,G,R,SES } \\
\text { A,G,R,SES } \\
\text { A,G,R,SES }\end{array}$ & $\begin{array}{l}\text { FUND } \\
\text { Naff } \\
\text { ATT }\end{array}$ \\
\hline Patee & 1994 & 2473 & USA & $\begin{aligned} r & =-0.12^{*} \\
r & =-0.13^{*} \\
r & =-0.09^{*}\end{aligned}$ & $\begin{array}{l}b=-0.703^{*} \\
b=-0.708^{*} \\
b=-.132\end{array}$ & $\begin{array}{l}\text { A,G,R,SES,X } \\
\text { A,G,R,SES,X } \\
\text { A,G,R,SES,X }\end{array}$ & $\begin{array}{l}\text { PSI-P } \\
\text { PSI-P } \\
\text { PSI-I }\end{array}$ \\
\hline Tittle & 1983 & 1993 & $\mathrm{IO}, \mathrm{NJ}, \mathrm{OR}$ & NA & (See text) & None & \\
\hline Welch & 1991 & 2667 & USA & NA & $\begin{array}{l}B=-0.078^{*} \\
B=-0.100^{*} \\
B=\mathrm{NS}\end{array}$ & $\begin{array}{l}\text { A,G,R } \\
\text { AGR } \\
\text { AGR }\end{array}$ & $\begin{array}{l}\text { Rel-I } \\
\text { Rel }=\mathrm{G} \\
\mathrm{Rel}=\mathrm{I} * \mathrm{G}\end{array}$ \\
\hline
\end{tabular}

${ }^{*} p<0.05$.

Notes: $r=$ correlation coefficient, $B=$ standardized regression coefficient, $b=$ unstandardized logistic regression coefficient, $p=$ probability level for regression coefficient, $\mathrm{NA}=$ bivariate results not available, $\mathrm{NS}=$ not significant. Controls: $\mathrm{A}=$ age, $\mathrm{G}=$ gender, $\mathrm{P}=$ political conservatism, $\mathrm{R}=$ race, $\mathrm{SES}=$ social class, $\mathrm{X}=$ informal sanction threat, TFA, past TF. Measures of religiosity: ATT $=$ church attendance, FUND $=$ fundamentalist affiliation, Naff $=$ no affiliation, PSI-P $=$ parish's social integration, medium, high, PSI-I individual-level integration into the parish. 
between individual religiosity and tax fraud in these Oklahoma-based investigations. Research is needed that is based on other cities, sets of cities, counties, states, or national samples-all of which have varying degrees of "moral communities." A variety of samples are needed because those samples that are high in religiosity are those where researchers are most likely to find significant effects of religion on behavior and attitudes (Stark 1996).

Nationwide investigations can take into account the varying degrees of community-level religiosity (Regnerus 2003). However, the only quasi-national studies on religion and tax fraud were done on Catholics (Patee, Milner, and Welch 1994; Welch, Tittle, and Patee 1991). Based on a national sample of Catholics in 36 representative non-Hispanic parishes, the two investigations came to somewhat different conclusions. In Patee, Milner, and Welch (1994), the degree of an individual's ties to the parish was unrelated to the likelihood of having committed tax fraud. However, there was a Level 2 or group effect on tax fraud. Patee, Milner, and Welch (1994) found that the mean level of religious social ties in a parish was predictive of less tax fraud. This grouplevel effect was independent of a number of controls including some demographic measures, and measures of sanction threat.

In contrast, in the other investigation, which used the same data set but different measures of key variables, individual-level religiosity was negatively related to projected or future tax fraud (Welch, Tittle, and Patee 1991). Group-level religiosity was also related to projected tax fraud. However, a multiplicative term measuring the interaction between individual- and parish-level religiosity, or their joint effect on tax fraud, was insignificant. Hence, these two investigations are split on whether there is a Level 1 effect, but are consistent in their findings on a Level 2 effect.

\section{Model Specification Problems in Past Research}

In all of these studies, both ones testing Level 1 and Level 2 models, the impact of religiosity may have been overstated due to lack of controls for possible covariates of religiosity. Two key controls are typically omitted from all of the existing studies on tax fraud and religion-familial and political bonds. In particular, no control was introduced for bonds to a spouse or family life. Family life is often a close covariate of religion as religious people are more bonded to family life than their counterparts (e.g., Stack 1985). In previous studies on tax fraud, religiosity may be capturing some of the effects of familial integration. If so, religion's influence may be overstated. Also, no controls were introduced for bonds to the present political regime. Political bonds are a second case of an omitted variable creating a possible problem of model misspecification. Persons who have confidence in the present government, which collects taxes, would be expected to have less favorable attitudes toward tax fraud. To the extent that religious people were disproportionately bonded to the present political regime (e.g., had relatively high confidence in the federal government in Washington), a control for such political bonds might confound the relationship between religion and attitudes toward tax fraud. Religious people in some historical situations may see the government as illegitimate. For example, in the present analysis the sample has many communist nations. To the extent that religious people had been persecuted by communist regimes (e.g., Bociurriw, Strong, and Laux 1975; Zaehner 1988), this may weaken the norm "thou shalt not steal." The norm may still carry weight on attitudes in general, but may be weakened in reference to the state seen as lacking legitimacy.

Furthermore, there is a third omitted variable in previous models of religion and tax fraud. The past research, while measuring objective social class status, does not control for perceived or subjective economic strain. To the extent that religion promotes an alternative stratification system based on morality, religious persons may not perceive as much economic strain as nonreligious persons (Stack 1983). However, economic strain may increase the acceptability of tax fraud out of sheer economic need. If so, the impact of religion in previous studies may actually be due, 
in part, to the association between religion and low economic strain. The present study includes controls for these neglected possible confounding factors.

\section{Meta-Analysis of Moral Community Effects}

A meta-analysis of 60 studies on religiosity and crime reported mixed results for the moral communities hypothesis (Baier and Wright 2001). Two subanalyses were done. The first metaanalysis compared mean effect sizes for two types of studies: 5 studies based on church members versus 55 studies based on the general population. In the first type of study, the sample was marked by a degree of religious selection, church members only. Church members form a "moral community" with opportunities for regular interaction and reinforcement of religious attitudes and beliefs. The sample in the second type of study was not restricted to church members but typically included church members and nonchurch members. The zero-order correlation between religious selectivity and the strength of the religion-crime association was $r=-0.30, p<0.05$. Hence, studies restricted to church members were more likely than their counterparts to find a strong impact of religion on criminality.

Baier and Wright (2001:14) also tested the moral communities hypothesis by dividing studies into two groups: those based on samples restricted to the West Coast (10 studies) and all others (50 studies). Stark (1996) has argued that because aggregate-level religiosity measures (e.g., church attendance rates, church membership rates) are lowest on the West Coast, the strength of the moral community is lower, and the reported associations between religion and deviance will be weaker. Baier and Wright (2001) reported that studies based on Pacific samples did not have significantly different effect sizes from studies based elsewhere in the United States. Hence, generally speaking, there is mixed support for the moral communities hypothesis in past research. However, there are some additional methodological issues that were not fully addressed in the Baier and Wright (2001) meta-analysis.

The two investigations by Patee and his colleagues, while having the advantage of being based on national samples, were both limited to Catholics. Catholics represent a minority of the American population. If the heterogeneity version of the moral community hypothesis is correct, the overall degree of religiosity in a community needs to be measured. In other words, the church membership or affiliate rate would include both Catholics and non-Catholics. Christian principles against theft, for example, can be reinforced by devout Protestants and other groups as well as Catholics. The religiosity levels of non-Catholics in the sample need to be taken into account for a complete test of the moral communities hypothesis. However, Patee and his colleagues had no data on non-Catholic religiosity levels. It is possible that the religious homogeneity version of the moral communities hypothesis is correct. If so, Patee's sample restriction would be appropriate. A second issue with this investigation is the indirect measure of religiosity. Patee, Milner, and Welch's (1994) study of Catholics had no data on the actual religiosity levels of people. Instead, it measured social ties to the parish in terms of indicators on how much an individual would miss these ties if they moved. Missing social ties to people in a church may not be an automatic measure of religiosity such as frequency of actual attendance, self-defined intrinsic religiosity, or the strength of religious beliefs. The Welch, Tittle, and Patee (1991) study did measure, in unreported findings, the parish's county's level of religiosity. In passing they noted that this was not related to individual-level deviance. Furthermore, a multiplicative term measuring the interaction between religion of the individual times the religiosity level of the parish was always nonsignificant.

The only study to document an interaction effect between group-level religiosity and the influence of individual-level religiosity on tax fraud was that done by Title and Welch (1983). However, the reported direction of this interaction did not support the moral communities hypothesis. Tittle and Welch (1983:670) determined that the strength of the religiosity-tax fraud relationship was directly related to the context of normative dissensus, lower social integration, 
low perceived conformity in the community, low aggregate religiosity, and high status inequality. Basically, when other social bonds are weak in the community, religion will have its greatest impact on criminality. For example, as social integration increases in their 27 contexts, the inhibiting influence of religion on tax fraud decreases (as opposed to increasing its inhibiting effect, as predicted). However, Tittle and Welch (1983) point out that their measures of contextual factors (e.g., age, gender, race, marital status, SES, city size, age categories) have serious limitations and that geographic contexts would be superior to the "approximated" contexts that were used (Tittle and Welch 1983; Welch, Tittle, and Patee 1991:160). In any event, their results are exactly the opposite of what would be anticipated from the moral communities perspective. By employing geographic-based measures of moral community, the present study helps to add some findings to a neglected area of research on tax fraud and religion.

\section{Attitudes and Deviant Behavior}

Some caution should be exercised in interpreting the results of the present study because it is based on attitudes toward tax fraud and not tax fraud offending. In general, there has been considerable debate over the association between attitudes and behavior (e.g., Bem 1970; Festinger 1964; Wicker 1969; Stein et al. 1992). Some research indicates lack of a relationship, while other research finds a significant relationship. For example, in the area of sex education, there is often no association between attitude change and actual sexual behavior (Stein et al. 1992). Nevertheless, many researchers see attitudes and behavior as mutually reinforcing. Indeed, behavior can "cause" or lead to attitudes as well as vice versa (e.g., Bem 1970; Festinger 1964). In models of personality, cognitions (which include attitudes) are often seen as largely inseparable from behavior (e.g., Caspi et al. 1994). For our purposes then, the study of attitudes may be picking up behavioral covariates of tax fraud. There is, however, little debate on the presence of a direct impact of attitudes on behavior in the field of the sociology of deviance.

In the area of deviant behavior there is considerable evidence that attitudes favoring deviance are predictive of actual deviant behavior. From the standpoint of a social learning theory of deviant behavior, positive definitions of deviance need to be learned through the socialization process in order to increase risk of actual deviant behavior. A book-length review of the relevant literature finds that attitudes favoring deviant behavior are generally the best predictors of individual-level deviance (Akers 2003). For example, in a study using national data, Warr and Stafford (1991) determined that there was a strong association between attitudes legitimizing stealing, cheating on exams, and marijuana use, on the one hand, and self-reported actual participation in each of the respective behaviors on the other. Matsueda and Heimer (1987) found that, for both blacks and whites, attitudes supporting deviance were the best predictors of delinquent behavior. Such attitudes were more important than having delinquent friends, coming from a broken home, socioeconomic status, age, residence in a troubled neighborhood, and other leading risk factors for delinquency.

While attitudes toward the acceptability of deviance are often one of the most important antecedents of deviance, the predictors of such attitudes have received relatively little attention (e.g., Akers 2003; Brown, Esbensen, and Geis 2001; Warr and Stafford 1991). An exception to the lack of rigorous analysis of attitudes supporting deviant behavior is the stream of research on attitudes toward the acceptability of suicide (e.g., Agnew 1998; Stack 1998; Stack, Wasserman, and Kposowa 1994). This subfield is especially significant for the purposes of the present investigation given its findings on religiosity. Religiosity has proven to be the most salient predictor of suicide attitudes. Religious affiliation, indicators of religious ritual such as church attendance, religious beliefs such as belief in a God and afterlife, and the self-reported level of religiousness have all been found to be significant predictors of suicide acceptability in the United States and other nations. In particular, the frequency of church attendance has often been the specific indicator 
of religious practices that is most predictive of individual-level approval of suicide. The present study extends the work on religion and suicide acceptability to the acceptability of tax fraud.

\section{Tax Fraud: The Link Between Attitudes and Behavior}

In the specific case of tax fraud, attitudes and behavior are linked. Available research indicates that tax fraud acceptability is a significant and often powerful predictor of reported tax fraud (Spicer and Lundstedt 1976; Varma and Doob 1998). This stream of research has the advantage of covering a number of nations that are in the present analysis. Research linking attitudes and behavior includes that from the United States, Sweden, the Netherlands, and Canada. Early crossnational survey research carried out by Strumpel (1969) found that negative attitudes toward tax offenders can make an important contribution toward the level of tax compliance within a country. Using data for three states, Tittle (1977) determined that tolerant attitudes toward tax cheating were predictive of tax fraud. Attitudes and behavior regarding tax fraud were also significantly linked in a study of Sweden by Warneryd and Walerud (1982). A study of 155 taxpayers in the Netherlands determined that their degree of tax fraud acceptability was positively related to self-reported tax fraud behavior (Hessing, Effers, and Weigel 1988). Smith's (1990) study of a national sample of 1,569 taxpayers determined that a scale of tax fraud acceptability was a leading determinant of reported tax fraud. In the case of 1,908 Canadian taxpayers, Varma and Doob (1998) found that the greater the acceptability of tax evasion the greater the tendency to have cheated on taxes. Given the association between TFA and reported tax fraud, which has been found not only in the United States, but elsewhere, we assume that the results of the present study could be applied to the prediction of tax fraud behavior.

\section{MethodS}

The sample consists of a set of 36 nations covered in the World Values Survey and for which data are available (Inglehart 2000). The World Values Surveys constitute the largest set of investigations ever conducted on the attitudes, beliefs, and values of scores of nations from around the world (Ingelhart and Baker 2000). The World Gallup Network performed most of the fieldwork and interviews. The data collection is designed to facilitate cross-national comparisons of basic values for a wide range of concerns. The survey is based on national representative samples of the adult population. Data in the present study are from Wave 2 of the Surveys, which was carried out during 1990-1993. The World Values Surveys have been regarded as one of the few databases from which investigations can draw sound cross-national comparisons of religious variables (Froese and Pfaff 2001:503-04). Complete data were available for 45,728 persons in 37 areas, 36 nations, and a sample of Moscow residents. The nations covered in the survey in the present study are: Argentina (637), Austria (1,321), Belarus (893), Belgium (2,544), Brazil $(1,731)$, Britain $(1,425)$, Bulgaria (952), Canada $(1,638)$, Chile $(1,462)$, China (943), Denmark (946), East Germany (1,306), Finland (518), France (888), Hungary (618), Iceland (531), India $(2,414)$, Ireland (967), Italy (1,945), Japan (874), Latvia (368), Mexico (1,428), Moscow (909), Netherlands (927), Nigeria (972), Northern Ireland (298), Norway (1,190), Poland (818), Portugal $(1,125)$, Romania $(1,051)$, Russia $(1,665)$, Slovenia $(945)$, Spain $(3,904)$, Sweden $(898)$, Turkey (944), USA $(1,709)$, and West Germany $(2,024)$. For further details on methodological issues concerning the World Values Surveys, see Inglehart (2000:1-20). Because population size varies across countries, data were weighted to take into account differential probabilities of selection. The weight variable used was that provided in the World Values Survey codebook.

Tax fraud acceptability is measured with a single item. The item is: "Please tell me whether or not you think that tax fraud can always be justified, never be justified or somewhere in between?" 
The subjects were given a set of possible responses ranging from $1=$ low approval of tax fraud to $10=$ high approval of tax fraud. There was skewness in the distribution of TFA (skewness $=$ 2.58 ), which was resolved by transforming the data to a logarithmic variable (skewness $<1$ ).

\section{Individual-Level Religion Measures}

For its Level 1 measures, this study uses both the religious affiliation of the individual and his or her degree of religiosity. First, a series of binary variables are created for religious affiliation. These match the available survey responses for religious affiliation found in the World Values Surveys. The religious affiliation variables are Buddhist $(0,1)$, Catholic $(0,1)$, Hindu $(0,1)$, Jewish $(0,1)$, Muslim $(0,1)$, Orthodox $(0,1)$, other religious affiliation $(0,1)$, and no denomination $(0,1)$. The benchmark category is Protestant. In order to handle missing data, a ninth binary variable was created and called "missing, unknown" $(0,1)$.

The level of individual religiosity is measured in terms of involvement in religious ritual, and also intrinsic religiosity. First, formal religiosity is measured as the frequency of attendance at religious services. Responses were coded on a seven-point index from never (0) to more than once a week (6). The most commonly used measure of religiosity in the literature on deviance is church attendance; thus we maximize comparability with past research on this first measure of religiosity (Baier and Wright 2001; Tittle and Welch 1983). Frequency of attendance at religious services is a measure of exposure to religious teachings and norms.

Two additional measures of individual-level religiosity measure the intrinsic meaning of religion. The first is based on response categories to the question: "Independently of whether you go to church or not, would you say you are: (1) a religious person; (2) not a religious person; (3) a convinced atheist; (9) don't know." A series of binary variables were introduced for each of the survey responses $(0,1)$. Those with missing information were collapsed with the "do not know" category. For such variables a benchmark category for comparison is required (Lewis-Beck 1980). The category "not a religious person" is the benchmark category. Hence, this intrinsic measure consists of three binary variables: religious person $(0,1)$, atheist $(0,1)$, and don't know/missing $(0,1)$.

A third measure of individual-level religiosity refers to responses to the question: "Do you find that you get comfort and strength from religion? (a) yes (b) no (c) don't know." Two binary variables were created. The first was dummy coded as 1 for those who found comfort in religion, 0 all others. The second is dummy coded as 1 for persons with unknown or missing information. Persons who stated that they found no comfort in religion constituted the reference group.

The second and third measures of religiosity capture self-defined or private or intrinsic religiosity. These are conceivably somewhat independent of attendance at religious services. However, previous cross-national research using religiosity measures has noted significant associations between various measures of this concept. For example, measures of individual-level religiosity generally correlate in the $r=0.92$ to $r=0.98$ range in the European nations (Halman and Petersson 2003:62-63). In fact, our results were largely unaffected by the selection of the ritual measure versus the intrinsic measure of religiousness. So some emphasis will be on reporting the results for the attendance measure, which was used in most previous research. Consideration was given to measuring the belief dimension of religion. However, many beliefs (e.g., even the belief in God as a creator of the universe) are not shared by all the world's religions (e.g., Smith 1991; Toropov and Buckles 2002). So belief was not included here.

\section{Moral Communities}

Several methodological strategies are used to test aspects and variants of the moral communities hypothesis (Regnerus 2003; Stark 1996). These are divided into two categories: 
(a) hierarchical linear models (HLM); (b) individual nation analysis. The results from the first HLM models will be provided in Tables $2-4$ and the results based on individual nation analysis are presented in Tables 5-6.

\section{Hierarchical Linear Models (HLM)}

The World Values Survey constitutes clustered or hierarchical data. Although information was collected on individuals, each survey was conducted independently in every country represented. Respondents may be described as "nested" in their country of residence. It may be argued that persons or respondents residing in the same country are more alike in their characteristics and responses to questions (e.g., scores on tax fraud) than respondents in another country. Thus, the issue of national context cannot be ignored, as there might be country-specific subject variation as well as across-country variation. Respondents might differ both within and across countries. Research suggests that nation of residence factors, such as national character, may be potentially confounding variables in cross-national research. In view of the different sources of variation and the possible impact of national character, ordinary least squares regression may not give accurate results of the effects of religiosity and other independent variables on tax fraud. A technique that simultaneously accounts for the hierarchically structured nature of the data is more likely to give reliable parameter estimates.

In the present study, a mixed modeling strategy was employed to ascertain both random and fixed effects. Parameters were estimated using restricted maximum likelihood (REML) in PROC MIXED, available within SAS, version 9.1 (SAS Institute 2004). The mixed model, also described as a hierarchical linear model (Bryk and Raudenbush 1992; Kreft and de Leeuw 1998) may be written as follows:

$$
y=\mathbf{X} \beta+\mathbf{Z} \gamma+\epsilon
$$

where

$y$ is a vector of responses on the outcome variable.

$\mathbf{X}$ is a known design matrix for the fixed effects (explanatory variables).

$\beta$ is a vector of unknown fixed-effect parameters to be estimated.

$\mathbf{Z}$ is a known design matrix for the random effects.

$\gamma$ is a vector of unknown random-effects parameters to be estimated.

$\in$ is a vector of stochastic errors.

A key assumption in the above model (1.0) is that both $\gamma$ and $\in$ are normally distributed. The model is described as mixed because it comprises both random and fixed-effects parameters.

The first set of measures of moral communities is employed in a series of hierarchical linear models. First, the presence of a moral community was measured in terms of a nation's mean level of attendance at religious services. The means for church attendance ranged from 0.12 in China to a high of 4.77 in Ireland. Hence, Ireland was judged to have the strongest moral community on this measure while China had the weakest. In results not reported here, nations were originally divided into two groups, one with low mean attendance and the other with high mean attendance scores. The median of the distribution of such means was used as the dividing line between groups. The results for this preliminary analysis, using a relatively crude measure high-low index of national religiosity, were essentially the same as those reported here. We report the results that use mean church attendance level for each nation.

A second strategy for measuring moral communities was to divide the nations into seven groups according to their dominant religion. The dominant religion was defined as the one with the highest percentage of affiliates in the CIA World Fact Book (CIA 1999). Nations that had Catholicism as their dominant religion included Argentina, Austria, and Belgium. Nations that 
were characterized as Orthodox included Bulgaria and Romania. Two nations had Islam as their dominant religion: Nigeria and Turkey. India was the only nation in the Hindu set. The benchmark group was the set of nations that was predominately Protestant. Nations that had Protestantism as their dominant religion included Britain, Denmark, and Finland. Perhaps the impact of living in a nation with a specific moral community (e.g., Islam) will be the principal way in which moral communities affect individual-level TFA (e.g., Regnerus 2003). Moral community effects on TFA may emerge within some religious traditions and not others. For example, living in a Muslim nation characterized by a high degree of religiosity among Muslims (e.g., institutions such as multiple daily prayer rituals), may affect TFA for individuals in such nations, including non-Muslims.

A third measure of a moral community in the HLM section of the analysis follows the definition from the meta-analysis of Baier and White (2001). Here we assume that religious affiliates (e.g., church members) will interact sufficiently to form a "moral community." Separate analyses were done for religious affiliates and nonaffiliates. If the moral community hypothesis is correct, the religiosity coefficient from the analysis of affiliates should be significantly greater than that for nonaffiliates. A $z$-test assessed whether the two coefficients were significantly different (Cohen 1983).

\section{Nation-Specific Analysis for the Moral Communities Hypothesis}

We performed a second analysis where we employed a different strategy to test the moral communities hypothesis. A second set of measures of moral communities was used in a set of results from 37 analyses, one from each nation. These measure the association between TFA and religiosity for each individual nation. The dependent variable in this set is whether there is a significant negative association between TFA and religiosity in each nation. This analysis, then, is based on 37 cases, one for each nation (including Moscow).

The first measure of a moral community is based on the religious heterogeneity meaning of moral community (Stark 1996). This is simply whether a nation has at least 50 percent of its population affiliating with any religion. For example, while the United States lacks a religion to which a majority of the population adheres, the vast majority of its population belongs to some religious group. Hence, it would have a "moral community." A second measure of moral community taps the religious homogeneity meaning of moral community. This is whether a nation has one religion to which a majority of the population belongs. For example, 98 percent of Italians belong to the Catholic Church, so Italy would constitute a "homogeneous" moral community. Additional analyses used alternative minimum percentages for defining a homogeneous moral community (e.g., 75 percent or more, 90 percent or more).

\section{Control Variables}

Controls are introduced for the covariates of religion and religiosity. We use three additional measures of social bonds, relevant to past work on religion and deviance. Because the present study is based on an adult sample, bonds to marriage, work, and government are of special interest (e.g., Sampson and Laub 1992). Bonds to marriage are measured with a binary variable where $1=$ married and $0=$ all other marital statuses (single, widowed, divorced). Bonds to work are measured using a series of binary variables corresponding to the World Values Survey response categories for employment status: employed 30 or more hours per week $(0,1)$, part-time employed or less than 30 hours $(0,1)$, self-employed $(0,1)$, not in labor force $(0,1)$, and other work status, or unknown, or missing $(0,1)$. The benchmark category is unemployed. Political ties are measured in terms of the response categories to the question on level of confidence in the government: quite a lot of confidence $(0,1)$, not very much confidence $(0,1)$, and none at all $(0,1)$. A fourth binary variable was added to save cases that were missing or unknown: confidence missing or unknown 
$(0,1)$. The benchmark category was the highest level of confidence, "A great deal of confidence." We assume that persons with very high levels of confidence in their government are most apt to see it as legitimate, and least apt to condone cheating on taxes paid to the government.

A control variable is introduced for economic strain, conceptualized as a gap between desired and actual economic outcomes (Agnew 1992). Thus, economic strain is measured as a subjective concept. The respondent was asked to rate his or her level of perceived financial dissatisfaction from one to ten, where $1=$ low financial dissatisfaction and 10 is the highest level of dissatisfaction. Income could not be used to measure objective economic strain because there are substantial differences in the purchasing power of the national currencies in the 36 nations under study. Two demographic control variables are age and gender. Age is coded in years. Older generations are often more conservative in their attitudes on deviance (e.g., Stack 1998; Stack, Wasserman, and Kposowa 1994). Gender is measured as female $=1$ and male $=0$. Women are generally more conservative in their beliefs and attitudes regarding the acceptability of deviance (e.g., Agnew 1998; Stack 1998).

\section{Missing Data}

The following strategies were used to handle missing cases. To maximize degrees of freedom as much as possible, we avoided eliminating missing cases from the analysis. In the World Values Survey, there are two main reasons why data become missing. In the classic case, respondents may fail or refuse to answer a given question. More often, however, missing data occur because a given question was not asked in a sampled country. For instance, questions on church attendance and tax fraud were not covered in all countries in the survey. In the latter situation, the resulting missing data were eliminated from statistical analysis. In the former, when dealing with categorical variables, the missing cases were coded as a covariate category and included in the regression models. This was done for the variables denomination, political confidence, and work status. For the ordinal variable financial dissatisfaction, two models were estimated. The first excluded missing cases $(N=545)$ and the second incorporated the means, substituted for missing values. Because parameter estimates remained virtually unchanged following mean substitution, the latter model was maintained. The 179 cases missing on age were eliminated from the analysis. Similarly, 82 respondents with missing information on gender were not included.

\section{National Residence}

Finally, the present study controls for national residence in its use of hierarchical linear models (HLM) techniques. HLM techniques first remove variation in the dependent variable across Level 2 units (herein nations). National residence controls for variability in national character. National character, or the average personality type in a nation, has often been shown to be associated with such variables as happiness and depression (e.g., Inglehart 1990; Inkeles 1990; Stack and Eshelman 1998). Differences in the historical conditions experienced by nations (e.g., war, conquest, long periods of unfulfilled expectations) can give rise to attitudes that may be linked to TFA. The bilevel models automatically remove variance in TFA that is based on between-nation variance. Although the relevant literature has not generally controlled for national character as a predictor of deviance, comparative research on suicide has done this for some years (e.g., Stack 1998). In the case of suicide acceptability, there are substantial differences among nations in the level of suicide acceptability that remain after major covariates are controlled (Stack 1998). We assume that there will be significant variation in TFA among nations as well. However, the research on suicide acceptability was based on relatively primitive statistical techniques (ordinary least squares; Stack 1998). So, the results of that previous related research stream are to be taken with some caution. 


\section{Analysis}

\section{Part I. Hierarchical Linear Models}

We began the analysis by estimating an unconditional means model in order to examine variation in tax fraud across and within countries. The unconditional means model expresses the individual-level responses on the outcome variable by combining two models that are linked, one at the individual or respondent level (Level 1) and the other at the country level (Level 2). The Level 1 model specifies a respondent's outcome as the sum of the intercept for the individual's country and a random error term that is associated with each respondent. At the second level, the country intercept was specified as a sum of the grand mean and random deviations from this mean. The estimated model had one fixed effect (the intercept) and two variance components, one representing the variation between countries on tax fraud, and the other component indexing variation among respondents within countries. Relevant results are shown in Table 2.

As Panel A shows, the covariance parameter estimates (random effects) are both statistically significant. The variance component between countries is $0.479(z=4.19, p<0.000)$, and that within countries is $4.882(z=154.57, p<0.000)$. These estimates suggest that countries in the World Values Survey differ in their average tax fraud scores, but that there is even more variation among respondents within countries. The significant variance components offer support for the national character argument, at least in the case of TFA. A clear implication of the finding is that using OLS to explain tax fraud in the World Values Survey would provide less accurate results because in OLS estimation the differentials that exist between countries are not taken into account, leading to the production of inefficient estimates or unreliable tests of statistical significance for some covariates. In the present case, for example, OLS results (not presented) showed that the effect of Catholic denomination was not significant $(b=0.044, t=1.34)$. In contrast, in mixed modeling that incorporated country variation, the effect of Catholic denomination was significant ( $b=0.105, t=2.56)$. Similarly, while full-time employment had no significant impact on tax fraud acceptability in the OLS regression $(-0.082, t=-1.51)$, it was significant in the mixed model analysis $(b=0.131, t=-2.45)$.

TABLE 2

ANALYSIS OF RANDOM EFFECTS: THE UNCONDITIONAL MEANS MODEL

\begin{tabular}{|c|c|c|c|c|c|}
\hline \multicolumn{6}{|c|}{ Panel A } \\
\hline \multicolumn{6}{|c|}{ Random Effects } \\
\hline Covariance parameters & Subject & Estimate & tandard Error & $z$-Value & Probability \\
\hline Intercept variance (across-country) & Country & 0.479 & 0.114 & 4.19 & 0.000 \\
\hline Residual (within-country) & & 4.883 & 0.031 & 154.57 & 0.000 \\
\hline Intra-class correlation & & 0.089 & & & \\
\hline \multicolumn{6}{|c|}{ Panel B } \\
\hline \multicolumn{6}{|c|}{ Fixed Effect } \\
\hline Effect & Estimate & Standard Error & do & $t$-Value & Probability \\
\hline Overall intercept (grand mean) & 2.533 & 0.114 & 36 & 22.09 & 0.000 \\
\hline-2 res log likelihood & \multicolumn{3}{|c|}{229,370} & & \\
\hline Number of countries & \multicolumn{3}{|c|}{37} & & \\
\hline Max obs per country & \multicolumn{3}{|c|}{4,039} & & \\
\hline Total observations & \multicolumn{3}{|c|}{47,818} & & \\
\hline
\end{tabular}


In an effort to determine what portion of variance is attributable to country differences in mean tax fraud, we computed an intra-class correlation coefficient. It indicates the proportion of variance in the response variable (tax fraud acceptability) that is due to cluster (country) membership. The calculated $(0.479 /[0.479+4.883])$ result yielded 0.089 . It means that 8.9 percent of the total variance (in tax fraud) can be explained by cluster (country) membership. The single fixed effect in Panel B of Table 2 is the grand mean, which indicates the average tax fraud acceptability (score) in the sample of countries studied.

The remainder of the analysis presents effects of religiosity and other variables on tax fraud. Model 1 of Table 3 is a fixed-effects equation that does not take into account individual country membership. Results in it were equivalent to estimation done with OLS in terms of significant parameters. Both Models 1 and 2 contain measures of religiosity. The first is frequency of attendance at religious services and a vector of dummy variables that indicate denominations, with Protestant serving as the reference group for comparison. As Model 1 in the table shows, service attendance had a significant effect on tax fraud acceptability. The greater the individual-level church attendance, the lower the TFA. The results show significant denominational differences in tax fraud acceptability. Muslims, Hindus, Buddhists, and members of the Orthodox church were less likely to support tax fraud compared to Protestants. Those without denomination, persons with other (unspecified) denominations, and individuals whose denominational affiliation was unknown or missing were less likely to support tax fraud than Protestants. Turning to the results on social bonds, the lower the level of confidence in the political system, the higher the degree of TFA. Married individuals were less likely to approve tax fraud. Work status was unrelated to tax fraud acceptability. The economic strain perspective was supported. The greater the financial dissatisfaction, the higher tax fraud acceptance. Both demographic controls were predictive of TFA, with females and older persons reporting lower TFA than their counterparts.

Model 2 of Table 3 maintains all the variables that were in the previous model. However, a hierarchical structure was specified whereby individuals were clustered within country of residence. A measure of national religiosity (average church attendance in each country) was also included in the analysis. As indicated by the two variance components in the table (intercept variance and residual), there was both between-country variation (intercept variance) in tax fraud acceptability and within-country (residual) variation. As observed in the unconditional means model earlier, results here show that even after including explanatory variables there was within-country variation in tax fraud acceptance.

As may be seen in the model, individual-level religiosity measures were related to TFA. Individual-level church attendance significantly reduced attitudes in favor of tax fraud $(b=$ $-0.074, t=-11.41)$. There were significant denominational differences in tax fraud approval, but they were not as pronounced as those reported in Model 1. Catholics, Buddhists, and persons with no denomination were significantly more likely than Protestants to find tax fraud acceptable, while Orthodox respondents tended to disapprove. No differences were observed between Hindus, Jews, Muslims, other denominations, and Protestants.

A key finding in Table 3, Model 2 regards the mean level of TFA. This Level 2 measure of religiosity was unrelated to individual-level TFA. National religiosity level did not reach statistical significance by conventional criteria.

Several measures of social bonds were predictive of TFA. Persons with little or no confidence in the government (political confidence) were much more likely to support tax fraud than those with a great deal of confidence. Individuals with unknown or missing confidence were also more in favor of tax fraud. The full-time employed were less likely to approve tax cheating compared to unemployed individuals. Married persons were less likely to approve tax fraud than nonmarried persons.

The measure of economic strain continued to be predictive of TFA. Financial dissatisfaction increased tax fraud acceptability. Both demographic controls were again related to TFA. Women 
TABLE 3

EFFECT OF RELIGIOSITY ON TAX FRAUD-ALL NATIONS

\begin{tabular}{|c|c|c|c|c|c|c|}
\hline \multirow[b]{2}{*}{ Variable } & \multicolumn{3}{|c|}{ Model $1^{1}$} & \multicolumn{3}{|c|}{ Model $2^{2}$} \\
\hline & $\beta$ & $t$-Value & Probability & $\beta$ & $t$-Value & Probability \\
\hline \multicolumn{7}{|l|}{ Fixed Effects } \\
\hline \multicolumn{7}{|l|}{ Religion } \\
\hline Church attendance & -0.096 & -15.51 & 0.000 & -0.074 & -11.41 & 0.000 \\
\hline \multicolumn{7}{|l|}{ Country mean } \\
\hline Religiosity score & & & & -0.040 & -0.38 & 0.707 \\
\hline \multicolumn{7}{|l|}{ Denomination } \\
\hline Catholic & 0.034 & 1.05 & 0.293 & 0.105 & 2.56 & 0.010 \\
\hline Orthodox & -0.528 & -6.93 & 0.000 & -0.212 & -2.74 & 0.006 \\
\hline Jewish & -0.002 & -0.01 & 0.992 & 0.319 & 1.45 & 0.147 \\
\hline Muslim & -1.082 & -16.40 & 0.000 & 0.144 & 1.35 & 0.177 \\
\hline Hindu & -0.934 & -15.55 & 0.000 & 0.107 & 0.82 & 0.414 \\
\hline Buddhist & -0.823 & -9.09 & 0.000 & 0.471 & 4.53 & 0.000 \\
\hline None & -0.189 & -5.41 & 0.000 & 0.223 & 5.13 & 0.000 \\
\hline Other & -0.276 & -5.25 & 0.000 & 0.107 & 1.64 & 0.100 \\
\hline Unknown/missing & -0.129 & -2.09 & 0.036 & -0.120 & -1.61 & 0.108 \\
\hline \multicolumn{7}{|l|}{ Social Bonds } \\
\hline \multicolumn{7}{|l|}{ Political confidence } \\
\hline Medium confidence & 0.234 & 4.01 & 0.000 & 0.055 & 0.95 & 0.341 \\
\hline Low confidence & 0.487 & 8.49 & 0.000 & 0.186 & 3.26 & 0.001 \\
\hline No confidence & 0.939 & 15.50 & 0.000 & 0.533 & 8.58 & 0.000 \\
\hline Unknown/missing & 0.487 & 9.29 & 0.000 & 0.301 & 4.00 & 0.000 \\
\hline \multicolumn{7}{|l|}{ Marital status } \\
\hline Married & -0.114 & -4.95 & 0.000 & -0.084 & -3.71 & 0.000 \\
\hline \multicolumn{7}{|l|}{ Work status } \\
\hline Full time & -0.077 & -1.41 & 0.157 & -0.131 & -2.45 & 0.014 \\
\hline Part time & -0.075 & -1.11 & 0.265 & -0.090 & -1.37 & 0.169 \\
\hline Self-employed & 0.021 & 0.33 & 0.742 & 0.116 & 1.83 & 0.066 \\
\hline Not in labor force & -0.086 & -1.53 & 0.126 & -0.099 & -1.81 & 0.070 \\
\hline Other work status & 0.128 & 1.49 & 0.136 & 0.161 & 1.97 & 0.048 \\
\hline \multicolumn{7}{|l|}{ Economic Strain } \\
\hline Financial dissatisfaction & 0.025 & 5.88 & 0.000 & 0.032 & 7.38 & 0.000 \\
\hline \multicolumn{7}{|l|}{ Demographics } \\
\hline Sex $($ female $=1)$ & -0.296 & -13.31 & 0.000 & -0.289 & -13.28 & 0.000 \\
\hline Age & -0.019 & -27.02 & 0.000 & -0.019 & -27.69 & 0.000 \\
\hline Intercept & 3.460 & & & 3.467 & & \\
\hline \multicolumn{7}{|l|}{ Random Effects } \\
\hline Intercept variance & - & & & 0.495 & $4.10^{*}$ & 0.0001 \\
\hline Residual & - & & & 4.686 & $154.53^{*}$ & 0.0001 \\
\hline Intra-class correlation & & & & 0.100 & & \\
\hline-2 res log likelihood & & 230,104 & & & 227,496 & \\
\hline Maximum obs per subject & & 47,818 & & & 4,039 & \\
\hline Number of cases & & 47,818 & & & 47,818 & \\
\hline Subjects (countries) & & & & & 37 & \\
\hline
\end{tabular}

${ }^{1}$ Contains fixed effects at individual level only.

${ }^{2}$ Contains fixed effects (at both levels) and random effects.

*based on $z$-value. 
were less likely to condone tax fraud than men and the older the respondent, the lower the degree of accepting tax fraud.

Arguably, religious service attendance is not the sole indicator of one's religiosity as it may not fully capture personal or intrinsic religiosity. In recognition of this possibility, two other religiosity measures were used in additional analyses, and results are presented in Table 4.

In Model 3, instead of worship attendance, the variable religious person was used. As may be seen in Model 3 (Table 4), religious persons were significantly less likely than the nonreligious to approve tax fraud ( $b=-0.292, t=-10.64$ ). Findings on denomination were more or less as observed when attendance was used. Again, national religiosity was unrelated to tax fraud acceptability. Catholics, Buddhists, and persons without religious affiliation were more likely to approve tax fraud, while Orthodox adherents were less likely. The results on the control variables were similar to those found in Table 3.

Comfort in religion was next substituted for service attendance as an indicator of personal/intrinsic religiosity. Relevant results of the data analysis are shown in Model 4 (Table 4). Respondents who found comfort in religion were considerably less likely to support tax fraud $(b=$ $-303, t=-11.07)$. Persons who said that they did not know and those with missing information were also less likely to accept tax fraud $(b=-107, t=-2.95)$. Denominational differences continued, with Catholics, Buddhists, and no denominations supporting tax fraud, and Orthodox opposing it. Results on the measures of social bonds continued to demonstrate the salience of marriage and political bonds as predictive of TFA. Financial dissatisfaction continued to predict TFA. Older persons and women were less approving of tax fraud than their counterparts.

In results not fully reported here, an HLM was estimated using still another measure of moral community: the dominant national religion. In a separate analysis not reported here, the various countries were grouped according to the major denomination of the country, as discussed in the Methods section. In effect, denomination at the country level was dummy coded with 1 each for predominantly Protestant countries, predominantly Catholic countries, predominantly Orthodox countries, predominantly Muslim/Islamic countries, and so on. Predominantly Protestant nations were used as the Level 2 (nation) variables. None of them reached statistical significance by conventional criteria. In addition, the variables introduced tremendous instability into the analysis due to multicollinear inefficiencies. Further examination using variance inflation factors (in OLS) and also bivariate correlational analysis revealed that the country-level variables were highly correlated with denomination at the individual level. They were therefore withdrawn from the data analysis in favor of more parsimonious results.

We found some supporting evidence for the moral communities hypothesis if we follow the methodology of Baier and Wright (2001). In an analysis not reported here, the hierarchical linear model was rerun for two groups: church members (affiliates) and nonmembers. For church members (those belonging to denominations), the coefficient on frequency of attendance at religious services was $-0.080(t=-11.84, p<0.0001)$. A separate analysis for nonmembers yielded a coefficient of $-0.041(t=-2.18, p<0.0293)$. A $z$-test was calculated for the difference in regression coefficients (Cohen 1981). The difference between the two groups was significant using a one-tailed or directional test $(Z=1.88, p<0.05)$. Service attendance among religious affiliates had more of a deterrent effect on TFA than attendance among nonmembers.

\section{Part II: Individual Nation Analysis}

To gain further insight into the relationship between religiosity and tax fraud acceptability, we performed an analysis of each nation. In this manner, the nations that depart from the expected relationship can be identified and further analyzed as deviant cases. Column 2 of Table 5 presents the results of 37 bivariate analyses. The zero-order Pearson's $r$ correlation for the religiosity measure of service attendance and TFA is listed. 
TABLE 4

EFFECT OF PERSONAL RELIGIOSITY ON TAX FRAUD-ALL NATIONS

\begin{tabular}{|c|c|c|c|c|c|c|}
\hline \multirow[b]{2}{*}{ Variable } & \multicolumn{3}{|c|}{ Model 3} & \multicolumn{3}{|c|}{ Model 4} \\
\hline & $\beta$ & $t$-Value & Probability & $\beta$ & $t$-Value & Probability \\
\hline \multicolumn{7}{|l|}{ Fixed Effects } \\
\hline \multicolumn{7}{|l|}{ Religiosity } \\
\hline Religious person & -0.292 & -10.64 & 0.000 & & & \\
\hline Atheist & -0.030 & -0.59 & 0.556 & & & \\
\hline Unknown/missing & -0.041 & -0.95 & 0.340 & & & \\
\hline Comfort in religion & & & & -0.303 & -11.07 & 0.000 \\
\hline Unknown/missing & & & & -0.107 & -2.95 & 0.003 \\
\hline Country mean religiosity & -0.069 & -0.66 & 0.516 & -0.058 & -0.66 & 0.587 \\
\hline \multicolumn{7}{|l|}{ Denomination } \\
\hline Catholic & 0.092 & 2.23 & 0.025 & 0.091 & 2.22 & 0.026 \\
\hline Orthodox & -0.265 & -3.44 & 0.000 & -0.251 & -3.26 & 0.001 \\
\hline Jewish & 0.286 & 1.29 & 0.195 & 0.301 & 1.36 & 0.173 \\
\hline Muslim & 0.191 & 1.78 & 0.074 & 0.192 & 1.79 & 0.072 \\
\hline Hindu & 0.101 & 0.77 & 0.443 & 0.118 & 0.90 & 0.371 \\
\hline Buddhist & 0.483 & 4.64 & 0.000 & 0.503 & 4.84 & 0.000 \\
\hline None & 0.228 & 5.21 & 0.000 & 0.233 & 5.35 & 0.000 \\
\hline Other & 0.116 & 1.78 & 0.074 & 0.119 & 1.84 & 0.065 \\
\hline Unknown/missing & -0.142 & -1.89 & 0.059 & -0.121 & -1.62 & 0.104 \\
\hline \multicolumn{7}{|l|}{ Social Bonds } \\
\hline \multicolumn{7}{|l|}{ Political confidence } \\
\hline Medium confidence & 0.057 & 1.00 & 0.316 & 0.059 & 1.02 & 0.307 \\
\hline Low confidence & 0.191 & 3.33 & 0.001 & 0.191 & 3.34 & 0.001 \\
\hline No confidence & 0.546 & 8.79 & 0.000 & 0.539 & 8.68 & 0.000 \\
\hline Unknown/missing & 0.319 & 4.23 & 0.000 & 0.313 & 4.15 & 0.000 \\
\hline Marital status $($ married $=1)$ & -0.082 & -3.62 & 0.000 & -0.082 & -3.63 & 0.000 \\
\hline \multicolumn{7}{|l|}{ Work status } \\
\hline Full time & -0.134 & -2.52 & 0.012 & -0.140 & -2.62 & 0.009 \\
\hline Part time & -0.090 & -1.37 & 0.169 & -0.095 & -1.45 & 0.148 \\
\hline Self-employed & 0.115 & 1.80 & 0.072 & 0.107 & 1.69 & 0.091 \\
\hline Not in labor force & -0.102 & -1.85 & 0.064 & -0.106 & -1.93 & 0.053 \\
\hline Other work status & 0.156 & 1.92 & 0.055 & 0.157 & 1.92 & 0.054 \\
\hline \multicolumn{7}{|l|}{ Economic Strain } \\
\hline Financial dissatisfaction & 0.033 & 7.75 & 0.000 & 0.034 & 7.79 & 0.000 \\
\hline \multicolumn{7}{|l|}{ Demographics } \\
\hline Sex $($ female $=1)$ & -0.287 & -13.17 & 0.000 & -0.280 & -12.83 & 0.000 \\
\hline Age & -0.070 & -27.57 & 0.000 & -0.019 & -27.04 & 0.000 \\
\hline Intercept & 3.446 & & & 3.394 & & \\
\hline \multicolumn{7}{|l|}{ Random Effects } \\
\hline Intercept variance & 0.513 & $4.10^{*}$ & 0.000 & 0.501 & $4.10^{*}$ & 0.000 \\
\hline Residual & 4.687 & $154.52^{*}$ & 0.000 & 4.686 & $154.53^{*}$ & 0.000 \\
\hline Intra-class correlation & 0.100 & & & 0.097 & & \\
\hline-2 res log likelihood & & 227,509 & & & 227,504 & \\
\hline Maximum obs per subject & & 4,039 & & & 4,039 & \\
\hline Number of cases & & 47,818 & & & 47,818 & \\
\hline Subjects (countries) & & 37 & & & 37 & \\
\hline
\end{tabular}

*based on $z$-value. 
TABLE 5

THE BIVARIATE CORRELATION BETWEEN RELIGIOSITY (CHURCH ATTENDANCE AND TAX FRAUD ACCEPTABILITY BY NATION

Nation

Bivariate Association

(A) Nations with Significant, Negative Bivariate Associations

Austria
Belgium
Britain
Brazil
Canada
Chile
Denmark
East Germany
Finland
France
Iceland
Ireland
Italy
Mexico
Netherlands
Northern Ireland
Norway
Romania
Slovenia
Spain
Sweden
Turkey
United States
West Germany

$-0.114^{*}$

$-0.176$

$-0.216^{*}$

$-0.074^{*}$

$-0.159^{*}$

$-0.064^{*}$

$-0.114^{*}$

$-0.089^{*}$

$-0.194^{*}$

$-0.124^{*}$

$-0.120^{*}$

$-0.154^{*}$

$-0.139^{*}$

$-0.069^{*}$

$-0.142^{*}$

$-0.109^{*}$

$-0.232^{*}$

$-0.059^{*}$

$-0.082^{*}$

$-0.138^{*}$

$-0.156^{*}$

$-0.116^{*}$

$-0.150^{*}$

$-0.247^{*}$

(B) Nations with Nonsignificant, Bivariate Associations

$\begin{array}{lr}\text { Argentina } & -0.021 \\ \text { Bulgaria } & 0.01 \\ \text { China } & 0.039 \\ \text { Hungary } & -0.004 \\ \text { India } & -0.017 \\ \text { Japan } & -0.054 \\ \text { Latvia } & -0.007 \\ \text { Moscow } & 0.033 \\ \text { Nigeria } & -0.042 \\ \text { Poland } & 0.014 \\ \text { Portugal } & -0.004 \\ \text { Russia } & -0.007 \\ \text { C) Nations with Significant Positive Bivariate Associations } & 0.087^{*} \\ \text { Belarus } & \text {. }\end{array}$

$* p<0.05$.

Source: World Values Surveys, 1990-1993. 
Panel A presents the nations where the bivariate association was negative and significant as predicted. In two-thirds of the nations, or 24 of 37, the negative association between attendance and TFA holds at the bivariate level. These nations include essentially all of the better-developed, Western European nations (e.g., Britain, France, Norway, and West Germany) and the three nations from North America (Canada, Mexico, and the United States). Panel B presents the correlations for the 12 of 37 nations that did not exhibit a significant association between attendance and TFA. Panel C lists a single nation, the former Soviet satellite Belarus, which exhibited a significant positive association between religiosity and TFA.

A likely concern is what conditions may account for the placement of nations into the three panels in Table 5. One possibility is that we are more apt to find the anticipated negative association between religiosity and TFA in nations with moral communities. To test this assertion, data were collected from the World Values Surveys to estimate the percentage of respondents in each nation that report having a religious affiliation. We followed Stark's (1996) notion of a moral community being a community with at least 50 percent of its members reporting a religious affiliation. There may be a "tipping effect" present such that at least 50 percent of a population needs to be religious in order for it to have an effect on others. We created a binary variable where nations with fewer than 50 percent of their respondents not reporting a religious affiliation were coded as 0 s. Nations with moral communities (50 percent or more respondents identify with a religious group) were coded as $1 \mathrm{~s}$. The dependent variable was also a dichotomy where $1=$ the significant negative association between religiosity and TFA exists (Panel A nations in Table 5) and 0 indicates that it does not (Panels B and $\mathrm{C}$ in Table 5). The results of a logistic regression analysis are given in Table 6.

From the odds ratio, nations marked by a moral community are fully 26.8 times more likely to have the expected negative association between TFA and religiosity. The logistic regression model explains about 39 percent of the variance in the dependent variable as reported by the Nagelkerke $R^{2}$ statistic.

To test Regnerus's (2003) thesis that moral communities that are homogeneous have the greatest impact on strengthening the association between religiosity and deviance, we created a new moral communities variable. Homogeneity of the moral community was defined as the presence of a religious group with affiliates constituting at least 50 percent of the national respondents. For example, 75 percent of Austrians report affiliations with the Catholic Church. Catholics in

TABLE 6

PREDICTING THE PRESENCE OF A RELIGIOSITY EFFECT ON TFA, INDIVIDUAL REGRESSIONS, THE EFFECT OF MORAL COMMUNITIES AND COMMUNIST REGIMES ON FINDING A NEGATIVE ASSOCIATION BETWEEN RELIGIOSITY AND TAX FRAUD ACCEPTABILITY

\begin{tabular}{|c|c|c|c|c|}
\hline Variable & $\begin{array}{l}\text { Model } 1 \\
\text { Odds Ratio }\end{array}$ & $\begin{array}{c}\text { Model } 2 \\
\text { Odds Ratio }\end{array}$ & $\begin{array}{l}\text { Model } 3 \\
\text { Odds Ratio }\end{array}$ & $\begin{array}{l}\text { Model } 4 \\
\text { Odds Ratios }\end{array}$ \\
\hline $\begin{array}{l}\text { Moral community, } 50 \% \text { or more of population } \\
\text { with any religious affiliation (moral } \\
\text { heterogeneity) }\end{array}$ & $26.83^{*}$ & & - & $11.84^{*}$ \\
\hline $\begin{array}{l}\text { Moral community, } 50 \% \text { or more of population } \\
\text { with a single affiliation (moral homogeneity) }\end{array}$ & - & $5.46^{*}$ & & \\
\hline Communist regime & - & - & $0.09^{*}$ & 0.278 \\
\hline Nagelkerke $R^{2}$ & 0.391 & 0.193 & 0.315 & 0.428 \\
\hline
\end{tabular}

${ }^{*} p<0.05$.

Note: $N=37$.

Source: World Values Surveys, 1990-1993. 
Austria would therefore constitute a homogeneous moral community. In contrast, in the United States, the largest single moral community consists of "Protestants." Since Protestants constitute only 32 percent of the respondents in the survey, there is an absence of a homogeneous moral community in the United States. Column 2 of Table 6 presents the results using the presence of a homogeneous moral community as the predictor variable. From the odds ratio, nations having homogeneous moral communities are 5.46 times more apt than those lacking such communities to exhibit a significant negative association between religiosity and TFA. The model explains 19 percent of the variance.

In results not fully reported here, other cutoff points were tried in the definition of homogeneous moral community. Nations were divided using a 75 percent criterion: that is, a homogeneous moral community required at least 75 percent of respondents affiliating with a single religion. The reported odds ratio was reduced to 2.25 and the Wald chi-square statistic was not significant. Even weaker results were found when the homogeneity cutoff point was increased to 90 percent. In a subsequent analysis, a quantitative measure of moral community was used. This referred simply to the percentage of the population with any religious affiliation. This was significantly related to explaining the presence of a negative association between religiosity and TFA in a nation. A 1 percent increase in religious adherents increased the odds of finding a significant negative association between religiosity and TFA by 3 percent. However, only 23 percent of the variance was explained. These results, together with those from Columns 1 and 2 of Table 6, suggest that the dichotomous heterogeneous conceptualization of a moral community provides the best fit for explaining the deviant cases in Table 5.

The present analysis also calls attention to the distribution of communist nations in Table 5. Most are in Panels B and C (Belarus, Bulgaria, China, Hungary, Latvia, Moscow, Poland, and Russia). A historical condition may explain the failure of religion to predict TFA in most communist nations. At the time of the interviews for the World Values Survey (mostly 1990-1991), they were undergoing a great transformation from communism to capitalism. To the extent that the interviewing in the surveys took place before the abolition of communism, people may have associated paying taxes with subsidizing a government that they viewed as illegitimate. As such, the generalized negative feelings about the rule of the Communist Party may have resulted in weak associations between religion and TFA. Perhaps both religious people and nonreligious people felt negatively about paying taxes to support a communist regime. Furthermore, religious persons had received considerably unequal and often oppressive treatment under some communist regimes (Bociurriw, Strong, and Laux 1975; Zaehner 1988). Religious persons, then, in particular, may have defined communist regimes as highly illegitimate. As such, the power of religious norms against theft (e.g., thou shalt not steal) may be rather weak or nonexistent in some communist nations when it comes to the special case of theft, tax fraud. A religious group may view tax fraud as more acceptable when a government has a history of oppressing them.

To test the influence of communism in predicting a negative association between religiosity and TFA, a logistic regression analysis was performed following the same strategy as in Table 6, Columns 1 and 2 . Here the predictor variable is a dichotomous variable where $1=$ communist nation and $0=$ all others. The results are in Table 6, Column 3. From the odds ratio (0.09), communist nations were 91 percent $(1-0.09)$ less apt than noncommunist nations to have a significant, negative association between religiosity and TFA. The model explains about 31 percent of the variance.

Table 6, Column 4 weights the relative importance of the presence of a moral community versus communist regime in predicting the expected negative association between religiosity and TFA in each nation. The moral community measure remains a significant predictor of finding the expected relationship. Nations with moral communities are 11.85 times more likely than those lacking a moral community to have a negative association between religiosity and TFA. Communist nations remain less apt to have such a negative relationship. However, the strength of this association is not significant $(p=0.10)$. The model explains 42 percent of the variance. 
While it is beyond the scope of this article to explain all individual deviant cases from Table 5, further analyses, not fully reported here, did explain some additional departures from the expected negative association between religiosity and TFA. One case in point is Nigeria. While there was no zero-order association between religious service attendance and TFA in Nigeria, the expected significant negative association emerged under controls for confidence in government and the other independent variables. Historical conditions may explain this puzzle. Nigeria is approximately 50 percent Muslim and 40 percent Christian (CIA 1999). The Christian part of the nation tried to set up an independent state (Biafra) in the Civil War in the 1960s. This effort failed and the Muslim majority continues to dominate the government, which apparently lowers confidence in government for the Christian minority. Hence, after controlling for confidence in government, the expected relationship between TFA and religious attendance emerged.

\section{Eastern Religions}

Three of the deviant cases from Panel B in Table 5 are Eastern nations (China, India, and Japan), whose dominant religious traditions are Confucianism, Hinduism, and Buddhism, respectively. Perhaps attendance at religious services does not have the same meaning in some of these particular nations. For example, in China there is a government-controlled and infiltrated religious sector. However, real church attendance may take place in the underground Christian churches that the government often persecutes. Because church attendance may be strongly discouraged in many locales, other measures of religiosity may better capture true religiosity levels. To ascertain if this is the case, additional regressions were run with intrinsic measures of religiosity as predictor variables. As anticipated, in results not fully reported here, self-defined religiosity (being a "religious person") was predictive of lower TFA in China. However, this relationship was barely significant $(p<0.05)$. A similar reanalysis was done for India. Intrinsic religiosity was a significant predictor of TFA in India as well. However, for Japan, even intrinsic religiosity was unrelated to TFA.

Japan is a nation with a very low level of tax fraud acceptability $($ TFA $=1.45)$, being in the bottom two nations in TFA. This low level is considerably lower than that found in European nations. A full 68 percent of Japanese say cheating on taxes is never justified compared to 49 percent of Europeans (Kisala 2003). Japanese culture has been found to place a high value on lawfulness, with a full 92 percent of the Japanese citing lawfulness as being important. When cultural norms strongly condemn a deviant behavior, there may be little variation left to be explained by other factors. Religiosity may have little bearing on such behavior, in this case TFA.

\section{Discussion}

Although national levels of religiosity, including the concept of a moral community, have been thought to promote social integration, the moral community hypothesis has seldom been tested in the area of deviant behavior. Furthermore, it has never been tested at the level of the nation-state for a set of nations with varied institutional and cultural contexts. The previous work on the influence of moral communities on the specific problem of tax fraud has been sparse, consisting only of three American-based investigations (Patee, Milner, and Welch 1994; Tittle and Welch 1983; Welch, Tittle, and Patee 1991). The results have not been consistent; some found evidence for a moral communities effect while some did not. As noted earlier, part of the inconsistency may rest in methodological problems and other differences among the studies. Turning to research results on Level 1 models, those that do not test the moral communities hypothesis, there are two additional studies from which to draw results (Grasmick, Bursik, and Cochran 1991; Grasmick, Kinsey, and 
Cochran 1991). The findings of these five existing American-based studies are somewhat tenuous. Although most have found that individual-level religiosity tends to reduce reported tax fraud, it is not clear if the results are somewhat inflated due to the omission of key control variables. The previous studies omit some key controls including marital ties, political bonds, and financial dissatisfaction. The present study contributes to the literature by correcting for these shortcomings and by extending the analysis to a nation-states, comparative perspective.

The results from tests of the moral community hypothesis in the present study, which used multi-level modeling procedures, produced mixed results. Removing the variance between nations, and using the frequency of attendance at religious services as the Level 2 variable, grouplevel religiosity had no bearing on individual-level TFA. This null finding was produced in two analyses: one using a dichotomous religious attendance variable (high vs. low attendance); and one using a continuous Level 2 variable, the mean level of attendance in each nation. Analyses using alternative measures of a moral community in HLM models were largely negative. These included a variable nesting the individuals into nations by major faith tradition (e.g., Protestant, Catholic, Hindu, Buddhist, Jewish, Muslim).

However, one HLM analysis did produce significant results for the moral communities hypothesis. When separate analyses were run for two subpopulations: religious affiliates and religious nonaffiliates, the slopes for the equation for the religious affiliates were significantly larger than those for the nonaffiliates. This particular result is consistent with one of two relevant findings from the meta-analysis by Baier and Wright (2001). Baier and Wright determined that studies based on church members were more apt to find stronger associations between individual-level religiosity and deviance. The studies in Baier and Wright (2001) were all based on samples from one nation, the United States. Hence, the present investigation allows us to generalize this finding to a larger set of nations. The failure of the HLM to produce very much evidence for the moral communities hypothesis may be related to the fact that the present investigation is using the nation as the unit of analysis for moral communities. Perhaps moral communities operate at smaller units of aggregation such as the church, community, county, or metropolitan area. However, as a check on this issue, a second set of analyses was done based on results from individual nations.

A second set of tests of the moral communities thesis was based on the correlation between TFA and religiosity found in each of the 37 nations, taken separately. Correlations between TFA and attendance were negative and significant in 24 of 37 nations. The hypothesis of heterogeneous moral communities (e.g., Stark 1996) was tested using a dichotomous variable. Nations with at least 50 percent of their population affiliated with any religion were significantly more likely to exhibit a significant and negative association between individual-level attendance and TFA. Furthermore, nations with at least 50 percent of their people with a homogenous affiliation, or single faith, were also more likely to exhibit the expected negative association. While both the heterogeneous and homogeneous variants of the moral communities hypothesis were supported, the heterogeneous version explained more of the variance in TFA.

However, a third variant of the moral communities hypothesis may have been more powerful than either of the variants that were tested in the present investigation. Work on both delinquency and suicide has often found conservative, or fundamentalist, Protestantism to be the best predictor of low deviant behavior (e.g., Pescosolido 1990; Regnerus 2003). Data in the World Values Survey were not available on specific Protestant denominations that could have been used to test this third theme in the moral communities hypothesis. Perhaps in future iterations of this survey, or related ones, data on more specific religious denominations will be available so that the conservative homogeneity version of the moral communities hypothesis can be adequately tested comparatively.

Several analyses, then, offered support for variants of the moral communities hypothesis. These findings suggest that the hypothesis can be applied to the nation-state as the unit of analysis. Future work is needed to see if national moral communities affect other forms of deviant behavior such as suicide, street crimes, and sexual deviance such as prostitution. Perhaps the moral 
communities thesis can be generalized to deviant behavior as a whole, or for certain categories of deviance (e.g., crimes without victims, street property crimes, violent crime).

\section{Communist Nations, Religion, and TFA}

Most of the 11 communist nations in the sample did not exhibit the expected negative association between religious attendance and TFA. Communist nations were fully 81 percent less apt than other nations to be marked by the anticipated association: the greater the religiosity the lower the TFA. The oppression of religious groups in these nations (e.g., Bociurriw, Strong, and Laux 1975; Froese and Pfaff 2001; Kaariainen 1989; Zaehner 1988) may have lessened the adherence to typical religious norms against theft. Religious taxpayers, in the context of religious oppression, may be less enthusiastic about being fully honest about paying taxes to a regime that oppresses them.

Most of the communist nations in the present study have now made the transition to democratic capitalist states. Approximately 80 percent of the former communist nations are in a state of religious revival (e.g., Froese and Pfaff 2001:484). With these cultural and political changes, perhaps the typical negative association between religiosity and TFA will reemerge in these new political economies. Because billions of dollars of tax revenue are at stake, and since these nations are struggling to integrate themselves into a favorable position in the world economy, it would be in the interests of these nations to find ways of decreasing the acceptability of tax fraud. Strengthening religious systems may be one way of achieving this goal.

In the Level 1 analysis, the present results suggest that religiosity is one of the most important correlates of TFA. Even after important controls are incorporated for factors such as confidence in the government and financial satisfaction, the greater the individual religiosity, the lower the approval of tax fraud. All three measures of individual religiosity (attendance, religious identification, finding comfort in religion) were powerful predictors of TFA. Unlike most research on religiosity and deviance, the present study was based on an adult sample. Hence, the present results add to the small literature confirming an association between religiosity and deviance among adults (Baier and Wright 2001).

New measures assessing the strengths social bonds were developed for this analysis. Confidence in government, in particular, was a strong predictor of TFA. Individuals who are highly confident in the regime were significantly less approving of tax fraud. Confidence in government may be a direct indicator of individuals' perceptions of the basic legitimacy of the state. One way of rebelling against a state that is viewed as being low in legitimacy is to cheat on taxes.

\section{Eastern Religions and TFA}

The present investigation also assessed the impact of Eastern religions on TFA. Controlling for the other predictors in the models, there emerged a relatively consistent pattern. Buddhists were more approving of tax fraud than Protestants. However, Hindus and Muslims were not significantly different from Protestants in level of TFA. Possibly, the religious teachings against theft may vary in intensity across religious faiths. However, a review of treatises on comparative religion did not yield any apparent major differences in the religious teachings against theft among these religions (Coward, Dargyay, and Neufeldt 1988; Halman and Riis 2003; Juergensmeyer 2003; Parringder 1971; Renard 2004; Smith 1991; Toropov and Buckles 2002; Zaehner 1988). One possible exception may be the teaching of the Buddha. The Buddha argued that crime, including theft, was mainly a function of poverty. He contended that if poverty were eliminated crime would cease to exist (Renard 2004:333). This externalization in the cause of crime might make it seem less unacceptable in Buddhist culture.

Turning to Judeo-Christian faiths, Catholics were significantly more approving of tax fraud than Protestants. Members of Orthodox churches tended to be less approving of tax fraud than 
their Protestant counterparts. There was no difference in the attitudes toward tax fraud between Jews and Protestants. These differences, or lack thereof, are difficult to explain. However, it is important to note that persons with no religious affiliation were typically the group that approved the most of TFA. In an analysis not reported here, differences between religious faiths in TFA became less noteworthy when religious nones were used as a benchmark instead of Protestants. Hence, the lack of religion is perhaps the key promoter of a culture favorable to tax fraud.

The fact that the present study is one of a few done on an adult sample and attitudes toward an adult-centered crime has some implications for research on religion and deviance. To some extent, young people's religiosity is forced upon them. This is less likely to be the case for adults. To the extent that religiosity levels among adults are "true" levels, religion would be expected to have more of a deterrent effect on deviance by adults. For example, unlike juveniles who might be forced to go to religious services by parents, adults who attend church are more likely to do so voluntarily, given lower levels of parental control (Ellison and Sherkat 1999). The results of the impact of religion on deviant behavior and attitudes may be stronger for research done on adult samples. Hence, the present study needs to be replicated for attitudes regarding youthcentered deviant behavior (e.g., cheating on exams, running away from home), after the necessary cross-national data become available.

This study has some implications for public policy concerning tax fraud. Much of the previous policy-oriented research has focused on increasing perceptions concerning the probability of punishment, especially of apprehension, for tax evasion (e.g., Klepper and Nagin 1989a, 1989b). However, the present study indicates that the promotion of participation in religion and confidence in government might be sound strategies for reducing tax fraud. Although it is beyond the scope of the present article to address exactly how these goals might be best accomplished, these were the two variables, among those that are amenable to manipulation, most closely tied to the variation in TFA. To the extent that governments can increase public trust and confidence, there should probably be less tax fraud and more revenue for government to use for its various programs.

\section{ACKNOWledgments}

This article is a revised version of a paper read at the annual meetings of the Society for the Study of Social Problems, San Francisco, August 14, 2004. Data were provided by the Inter-University Consortium for Political and Social Research, University of Michigan, Ann Arbor, MI.

\section{REFERENCES}

Agnew, R. 1992. Foundations for a general strain theory. Criminology 30:47-88.

1998. The approval of suicide: A social psychological model. Suicide \& Life Threatening Behavior 28:205-25.

Akers, R. 2003. Criminological theories: Introduction and evaluation. Los Angeles, CA: Roxbury.

Baier, C. and B. R. E. Wright. 2001. If you love me keep my commandments: A meta-analysis of the effect of religion on crime. Journal of Research in Crime and Delinquency 38:3-21.

Bem, D. 1970. Beliefs, attitudes and human affairs. Oxford, UK: Brooks-Cole.

Bociurriw, B., J. W. Strong, and J. K. Laux. 1975. Religion and atheism in the U.S.S.R. and Eastern Europe. New York: Macmillan.

Brown, S., F. A. Esbensen, and G. Geis. 2001. Criminology: Explaining crime and its context. Cincinnati, OH: Anderson Publishing.

Bryk, A. S. and S. W. Raudenbush. 1992. Hierarchical linear models: Applications and data analysis methods. Newbury Park: Sage Publications.

Burkett, S. and B. Warren. 1987. Religiosity, peer associations, and adolescent marijuana use: A panel study of underlying causal structures. Criminology 31:119-34.

Casey, J. and Scholz, J. 1991. Beyond deterrence: Behavior decision theory and tax compliance. Law and Society Review 24(3):837-61.

Caspi, A., T. E. Moffitt, P. A. Silva, M. Stouthamer-Loeber, R. F. Krueger, and P. S. Schmutte. 1994. Are some people crime prone? Replication of the personality-crime relationship across countries, genders, races, and methods. Criminology 32:163-95. 
Central Intelligence Agency. 1999. World fact book. Dulles, VA: Brasseys.

Clotfelter, C. 1983. Tax evasion and tax rates. Review of Economics and Statistics 65:363-73.

Cohen, A. 1983. Comparing regression coefficients across sub samples. Sociological Methods and Research 12:77-94.

Coward, H., E. Dargyay, and R. Neufeldt, eds. 1988. Reader in eastern religions. Waterloo, Ontario: Wilfrid Laurier University Press.

Dean, P., T. Keenan, and F. Kenney. 1980. Taxpayer attitudes to income tax evasion: An empirical study. British Tax Review 28(1):28-44.

Durkheim, E. 1961. Moral education. New York: Free Press.

Ellison, C. G., J. A. Burr, and P. McCall. 1997. Religion homogeneity and metropolitan suicide rates. Social Forces 76:273-99.

Ellison, C. G. and D. Sherkat. 1999. Identifying the semi-involuntary institution: A clarification. Social Forces 78:793800 .

Festinger, L. 1964. Behavioral support for opinion change. Public Opinion Quarterly 28:404-17.

Froese, P. and S. Pfaff. 2001. Replete and desolate markets: Poland, East Germany, and the new religious paradigm. Social Forces 80:481-507.

Grasmick, H. and R. Bursik. 1990. Conscience, significant others, and rational choice: Extending the deterrence model. Law and Society Review 24:837-61.

Grasmick, H., R. Bursik, and J. Cochran. 1991. Render unto caesar what is caesar's: Religiosity and taxpayers inclinations to cheat. Sociological Quarterly 32:251-66.

Grasmick, H., K. Kinsey, and J. Cochran. 1991. Denomination, religiosity and compliance with the law: A study of adults. Journal for the Scientific Study of Religion 30:99-107.

Hackney, C. H. and G. Sanders. 2003. Religiosity and mental health: A meta analysis of recent studies. Journal for the Scientific Study of Religion 42:43-55.

Hallman, L. and T. Petersson. 2003. Differential patterns of secularization in Europe. In Religion in secularizing society: The Europeans' religion at the end of the twentieth century, edited by L. Hallman and O. Riis, pp. 48-75. Boston: Brill.

Hallman, L. and O. Riis, eds. 2003. Religion in secularizing society: The Europeans' religion at the end of the twentieth century. Boston: Brill.

Hessing, D., H. Effers, H. Robben, and P. Webley. 1992. Does deterrence deter? Measuring the effect of deterrence on tax compliance in field studies and experimental studies. In Why people pay taxes, edited by J. Slemrod. Ann Arbor: University of Michigan Press.

Hessing, D., H. Effers, and R. Weigel. 1988. Exploring the limits of self-reports and reasoned action: An investigation of the psychology of tax evasion behavior. Journal of Personality and Social Psychology 54:405-13.

Hirschi, T. 1969. Causes of delinquency. Berkeley: University of California Press.

Inglehart, R. 1990. Culture shift in advanced industrial societies. Princeton: Princeton University Press.

- 2000. World values surveys and European values surveys, 1981-1984, 1990-1993, and 1995-1997. Ann Arbor, MI: Inter-University Consortium for Political and Social Research.

Inglehart, R. and W. Baker. 2000. Modernization, cultural change, and the persistence of traditional values. American Sociological Review 65:19-51.

Inkeles, A. 1990. National character revisited. Tocqueville Review 12:83-112.

Juergensmeyer, M., ed. 2003. Global religions: An introduction. New York: Oxford University Press.

Kaariainen, K. 1989. Discussion of scientific atheism as a soviet science. Helinski: Suomalainen Tiedeakaternia.

Kisala, R. 2003. Japanese religiosity and morals. In Religion in secularizing society: The Europeans' religion at the end of the twentieth century, edited by L. Hallman and O. Riis, pp. 205-22. Boston: Brill.

Klepper, S. and D. Nagin. 1989a. Tax compliance and perceptions of the risks of detection and criminal prosecution. Law and Society Review 23(2):209-40.

- 1989b. The deterrent effect of perceived certainty and severity of punishment revisited. Criminology 27(4):72146.

Koenig, H. G. and D. B. Larson. 2001. Religion and mental health: Evidence for an association. International Review of Psychiatry 13:67-78.

Koenig, H. G., M. E. McCullough, and D. B. Larson. 2001. Handbook of religion and health. New York: Oxford University Press.

Kreft, I. and J. de Leeuw. 1998. Introducing multilevel modeling. London: Sage Publications.

Land, K., P. McCall, and L. Cohen. 1990. Structural covariates of homicide rates. American Journal of Sociology 95:92263.

Lewis-Beck, M. 1980. Applied regression analysis. Thousand Oaks, CA: Sage.

Matsueda, R. and K. Heimer. 1987. Race, family structure and delinquency. American Sociological Review 52:826-40.

Parrinder, G. 1971. World religions: From ancient times to the present. New York: Facts on File.

Patee, T., T. Milner, and M. Welch. 1994. Levels of social integration in group contexts and the effects of informal sanction threat on deviance. Criminology 32:85-106.

Pescosolido, B., 1990. The social context of religious integration and suicide. Sociological Quarterly 31:337-57. 
Regnerus, M. D., 2003. Moral communities and adolescent delinquency: Religious contexts and community social control. Sociological Quarterly 44:523-34.

Renard, J. 2004. The handy religion answer book. New York: Barnes and Noble.

Sampson, R. and J. Laub. 1992. Crime and deviance over the life course. American Sociological Review 55:609-27.

SAS Institute. 2004. SAS/STAT, the mixed procedure [computer software], version 9.1. Cary: NC: SAS Institute, Inc.

Scott, W. J. and H. Grasmick. 1981. Deterrence and income tax cheating. Journal of Applied Behavioral Science 17:395408.

Sheffrin, S. and R. Triest. 1992. Can brute deterrence backfire? Perceptions and attitudes in taxpayer compliance. In Why people pay taxes, edited by J. Slemrod. Ann Arbor: University of Michigan Press.

Smith, H., 1991. The world's religions. New York: Harper.

Smith, K., 1990. Integrating three perspectives on noncompliance. Criminal Justice and Behavior 17:350-69.

Spicer, M. W. and B. B. Lundstedt. 1976. Understanding tax evasion. Public Finance 31:295-305.

Stack, S. 1983. The effect of religious commitment on suicide: A cross-national analysis. Journal of Health and Social Behavior 24:362-74.

1985. The effect of religious-family integration on suicide. Journal of Marriage and the Family 47:431-47.

1998. Gender, marriage, and suicide acceptability. Sex Roles 37:501-20.

Stack, S. and R. Eshelman. 1998. Marital status and happiness: A comparative analysis. Journal of Marriage and the Family 60:527-36.

Stack, S., I. Wasserman, and A. Kposowa. 1994. The effects of religion and feminism on suicide ideology. Journal for the Scientific Study of Religion 33:110-21.

Stark, R. 1996. Religion as context: Hellfire and delinquency one more time. Sociology and Religion 57:163-73.

Stein, D., E. Witzum, D. Brom, A. DeNour, and A. Elizur. 1992. The association between adolescents' attitudes towards suicide and their psychosocial background and suicidal tendencies. Adolescence 27:949-59.

Strumpel, B. 1969. Contribution of survey research. In Quantitative analysis in public finance, edited by A. Peacock, pp. 29-32. New York: Praeger.

Thurman, Q. 1989. General prevention of tax evasion. Journal of Quantitative Criminology 5:127-46.

Thurman, Q. C. St John, and L. R. Riggs. 1984. Neutralization and tax evasion. Law Policy 6:309-27.

Tittle, C. R. 1977. Sanction, fear, and the maintenance of social order. Social Forces 55:579-96.

Tittle, C. and M. Welch. 1983. Religiosity and deviance: Towards a contingency theory of constraining effects. Social Forces 61:653-82.

Toropov, B. and L. Buckles. 2002. World religions. Indianapolis: Pearson Educational Publishers.

Varma, K. and A. Doob. 1998. Deterring economic crimes: The case of tax evasion. Canadian Journal of Criminality 40:165-84.

Vogel, J. 1974. Taxation and public opinion in Sweden. National Tax Journal 27:499-513.

Warneryd, K. and B. Walerud. 1982. Taxes and economic behavior: Some interview data on tax evasion in Sweden. Journal of Economic Psychology 2:187-211.

Warr, M. and M. Stafford. 1991. The influence of delinquent peers: What they think and what they do. Criminology 29:851-65.

Welch, M., C. Tittle, and T. Patee. 1991. Religion and deviance among adult Catholics: A test of the moral communities hypothesis. Journal for the Scientific Study of Religion 30:159-72.

Wicker, A. W. 1969. Attitudes vs. actions. Journal of Social Issues 4:41-75.

Zaehner, R. C. 1988. Encyclopedia of the world's religions. New York: Barnes and Noble. 